\title{
Study of physico-chemical and biochemical parameters during rotary drum composting of water hyacinth
}

\author{
D. Sarika $\cdot$ Jiwan Singh $\cdot$ Ravi Prasad $\cdot$ \\ Isha Vishan $\cdot$ V. Sudharsan Varma • \\ Ajay S. Kalamdhad
}

Received: 23 September 2013/Accepted: 17 May 2014/Published online: 15 August 2014

(c) The Author(s) 2014. This article is published with open access at Springerlink.com

\begin{abstract}
Background Water hyacinth (Eichhorniacrassipes) is one of the most uncompromising weeds in the whole world. Its adverse effects due to fast growth rate are main physical interference with fishing and navigation. Water hyacinth also causes eutrophication due to the large release of organic nutrients after its degradation, consequentially deterioration of water quality and also adversely affecting aquatic flora and fauna. Therefore, composting is one of the best methods for control and utilization of water hyacinth. Water hyacinth being the plant material is rich in cellulose, hemicellulose, and lignin content which hinders the rate of degradation during composting. The raw materials including water hyacinth along with sawdust and cattle manure in five different proportions trial 1 (10:0:0), trial 2 $(8: 1: 1)$, trial $3(7: 2: 1)$, trial $4(6: 3: 1)$, and trial $5(5: 4: 1)$ were composted using rotary drum composter.

Results Final product of water hyacinth composting was flourishing of nutrients such as nitrogen, phosphorus, sodium, potassium, calcium, and magnesium. The lignin reduction in all the five trials was obtained between 10 and $40 \%$. The reduction in cellulose was observed ranging from 4 to $55 \%$ in different trials. Similar as cellulose and lignin, hemicellulose was also reduced about $11-46 \%$ in all five trials during the process.

Conclusion The maximum reduction inorganic matter, lignin, cellulose and hemicellulose was observed in trial 4;
\end{abstract}

D. Sarika · J. Singh $(\bowtie) \cdot$ R. Prasad · I. Vishan .

V. S. Varma · A. S. Kalamdhad

Department of Civil Engineering, Indian Institute of Technology

Guwahati (IITG), Guwahati 781039, Assam, India

e-mail: jiwansingh95@gmail.com

D. Sarika

e-mail: d.sarika28@gmail.com whereas, the nutrient contents (nitrogen, phosphorus, Na, $\mathrm{K}, \mathrm{Ca}$, and $\mathrm{Mg}$ ) were increased significantly during the process. On analyzing the FTIR results, trial 4 showed that aliphatic and polysaccharides have easily degraded and aromatic compounds have increased with composting time in trial 4.

Keywords Water hyacinth - Rotary drum composter . Lignin $\cdot$ Cellulose $\cdot$ Hemicellulose $\cdot$ Reducing sugars

\section{Introduction}

Water hyacinth (Eichhorniacrassipes) or pani-meteka in Assam, India is found abundantly in almost every water body of the Assam state. It is an inherent of Brazil and other central South American countries, but now it is widespread in lakes, slowly moving rivers and swamps in most countries of the world lying between $40^{\circ} \mathrm{N}$ and $40^{\circ} \mathrm{S}$ includes India, South Africa, and the USA (Malik 2007).Water hyacinth has seen as one of the most productive plants in the world and it has many advantages for human beings (Abbasi and Ramasamy 1999). It has been used for biogas production, dye removal, as a source of bio fuel, bioelectricity generation, animal feed, agriculture, and household articles manufacturing (Malik 2007).Its function as a food source for aquatic bio-phage, water current controls, purifies turbid water through sedimentation and sorption, and reduces pollutants through absorption of minerals (Baruah 1984). The neutral pH, high concentration of macronutrients in water, optimum temperatures $\left(28-30{ }^{\circ} \mathrm{C}\right)$ and high intensity of light are favorable conditions for flourishing water hyacinth (Center et al. 2002). Due to its fast growth, it causes several problems in the affected water bodies such as, physical interference with 
fishing, navigation, irrigation systems, hydroelectric power schemes and increased sedimentation and blockage in canals, rivers can give rise to risk of flooding (Malik 2007). Attempts to control this weed have caused high expenses and labour requirements, which only aids in temporary removal of this weed. If it is not controlled and utilized properly, aquatic ecosystem will be affected adversely. But, the water hyacinth possesses a great ability if seen as raw material for industries or if assimilated into agricultural practices (Gunnarsson and Petersen 2007). Therefore, composting can be seen as one of the sustainable option for utilization of water hyacinth into agricultural field.

Water hyacinth being a plant biomass is primarily composed of three constituents such as lignin, cellulose, and hemicellulose. This plant is fibrous in nature, and contains a high energy and protein content, due to which it can be utilized for numerous practical applications (Malik 2007). The amount of hemicellulose and cellulose is moderately high in water hyacinth plant but these substances are hardly available for microorganisms due to strong association with the lignin present in the plant cell. Since, the biodegradation of lignin is very difficult in the nature (Patel et al. 1993). The lignocellulose is the major organic compound that limits the rate of composting of agricultural and forestry waste, among which the lignin acts as a major contributor of speed limiting compound (Patel et al. 1993).

Lignin degradation is predominantly an aerobic process, and in an anaerobic condition, lignin can persevere for longer time (Van 1994). Lignin being the most recalcitrant component of the plant cell wall, its higher proportion reduces bioavailability of the substrate (Haug 1993). The most abundant constituent of plant is the cellulose and hemicelluloses, which can be easily degraded to a large extent during composting period, but a portion of it is associated with lignin molecule; maximum degradation could not be achieved. Therefore, to achieve the quality of water hyacinth compost, it is required to study the degradation of lignin, cellulose and hemicelluloses during the composting process without inoculating it with external lignin degrader. Rotary drum composting of water hyacinth being the method which provides high-rate composting of as a result of proper mixing of compost mixture and higher thermophilic temperature; therefore it has been adopted to achieve high degradation rate (Singh and Kalamdhad 2013a, b, 2014). Hence, five different trials were performed with different proportions of water hyacinth, sawdust and cattle manure and the best proportion of these materials was evaluated for achieving maximum reduction of lignin, cellulose and hemicellulose under ideal conditions.

\section{Materials and methods}

The compost materials

Water hyacinth was collected from the industrial area situated in Amingaon, North Guwahati, Assam, India. Cattle manure and sawdust were obtained from nearby dairy farm and saw mill, respectively. The water hyacinth was collected and then shredded into size of $1 \mathrm{~cm}$ approximately for uniform substrate distribution. Cattle manure and sawdust were properly mixed together in the desirable ratio and finally mixed with shredded water hyacinth. Five trials (Trials 1, 2, 3, 4, and 5) were performed during rotary drum composting of water hyacinth in combination with cattle manure and sawdust. Sawdust was used as a bulking agent. Mixtures of these materials were composted in rotary drum composter for 20 days. The drum was rotated after every $24 \mathrm{~h}$ for proper aeration and homogenized mixing of materials for degradation. The compost was prepared with different proportions of waste composition as described in Table 1.

\section{Rotary drum composter design}

A rotary drum composter of $550 \mathrm{~L}$ capacity was used as adopted by Kalamdhad et al. (2009a, b). The main unit of the composter, i.e., the drum is of $0.92 \mathrm{~m}$ in length and $0.9 \mathrm{~m}$ in diameter, made up of a $4 \mathrm{~mm}$ thick metal sheet.

Table 1 Waste composition and initial characterization of raw materials

\begin{tabular}{|c|c|c|c|}
\hline \multirow[t]{2}{*}{ Trials } & \multicolumn{3}{|l|}{ Raw materials } \\
\hline & $\begin{array}{l}\text { Water } \\
\text { Hyacinth } \\
(\mathrm{kg})\end{array}$ & $\begin{array}{l}\text { Cattle } \\
\text { manure } \\
(\mathrm{kg})\end{array}$ & Saw dust $(\mathrm{kg})$ \\
\hline Trial 1 (10:0:0) & 150 & 0 & 0 \\
\hline Trial $2(8: 1: 1)$ & 120 & 15 & 15 \\
\hline Trial $3(7: 2: 1)$ & 105 & 30 & 15 \\
\hline Trial 4 (6:3:1) & 90 & 45 & 15 \\
\hline Trial $5(5: 4: 1)$ & 75 & 60 & 15 \\
\hline $\mathrm{pH}$ & 5.79 & 6.65 & 6.15 \\
\hline $\begin{array}{l}\text { Moisture content } \\
(\%)\end{array}$ & 85.93 & 80.92 & 10.01 \\
\hline Organic matter $(\%)$ & 72.641 & 97.871 & 72.054 \\
\hline $\begin{array}{l}\text { Acid insoluble } \\
\text { lignin }(\%)\end{array}$ & $9.655 \pm 0.23$ & $20 \pm 2.12$ & $41.355 \pm 1.17$ \\
\hline $\begin{array}{l}\text { Acid soluble lignin } \\
(\%)\end{array}$ & $1.801 \pm 0.10$ & $1.27 \pm 0.02$ & $0.862 \pm 0.02$ \\
\hline Cellulose $(\%)$ & $15.78 \pm 0.51$ & $49.87 \pm 2.02$ & $37.89 \pm 2.04$ \\
\hline Hemicellulose $(\%)$ & 27 & 11.8 & 4.3 \\
\hline $\begin{array}{l}\text { Reducing sugars } \\
(\%)\end{array}$ & $0.655 \pm 0.01$ & $1.386 \pm 0.38$ & $1.942 \pm 0.12$ \\
\hline
\end{tabular}


The drum was rotated every $24 \mathrm{~h}$ for proper agitation and aeration of raw materials inside the composter. The samples were collected through grab sampling from different locations, mainly from the mid span and end terminals of the rotary drum composter with a compost sampler to minimize disturbance of the adjacent materials. All the grab samples were thoroughly mixed together to make a homogenized sample. Triplicates homogenized samples were collected on $0,4,8,12,16$, and 20th day after manual turning.

The analytical methods

Temperature was measured daily using a digital thermometer before turning the compost material. Triplicate samples were collected and dried at $105{ }^{\circ} \mathrm{C}$ in hot air oven for $24 \mathrm{~h}$ and moisture content was calculated, dried samples were ground to pass to $0.2 \mathrm{~mm}$ sieves and stored for further analysis. Later, the samples were analyzed for following parameters: $\mathrm{pH}(1: 10, \mathrm{w} / \mathrm{v}$ waste:water extract) and volatile solids (VS) by combustion at $550{ }^{\circ} \mathrm{C}$ for $2 \mathrm{~h}$. Total nitrogen was measured using the Kjeldahl method, $\mathrm{NH}_{4}-\mathrm{N}$ and $\mathrm{NO}_{3}-\mathrm{N}$ using $\mathrm{KCl}$ extraction (Tiquia and Tam 2000); available total phosphorus (acid digest) was analyzed using the stannous chloride method (APHA 2005).The Flame photometer (Systronic 128) was used for analysis of Na, K and $\mathrm{Ca}$ concentration and atomic absorption spectrometer (AAS) (Varian Spectra 55B) was used for analysis of $\mathrm{Mg}$ after the digestion of $0.2 \mathrm{~g}$ sample with $10 \mathrm{~mL}$ of $\mathrm{H}_{2} \mathrm{SO}_{4}$ and $\mathrm{HClO}_{4}$ (5:1) mixture in block digestion system (Pelican Equipments Chennai, India) Pelican for $2 \mathrm{~h}$ at $300{ }^{\circ} \mathrm{C}$.

Lignin was determined in $0.3 \mathrm{~g}$ (dry weight) portions of each sample using National renewable energy laboratory (NREL) procedure (Templeton and Ehrman 1995; Ehrman 1996). Cellulose was obtained using method adopted by Updegraff (1969) and hemicellulose was determined from the difference between neutral detergent fiber (NDF) and acid detergent fiber (ADF) using method provided by Goering and Van (1975). Reducing sugars were obtained using DNS method Miller (1959).

\section{Results and discussions}

Physico-chemical analysis

Temperature profiles for all the five trials are shown in Fig. 1. The rise in temperature was caused mainly by the metabolic heat generated during degradation of organic matter. In trial 1 (control), the maximum temperature recorded about $36.2{ }^{\circ} \mathrm{C}$ on day 6 , which was the least peak achieved as compared to other trials due to only water hyacinth was used for composting (without addition of

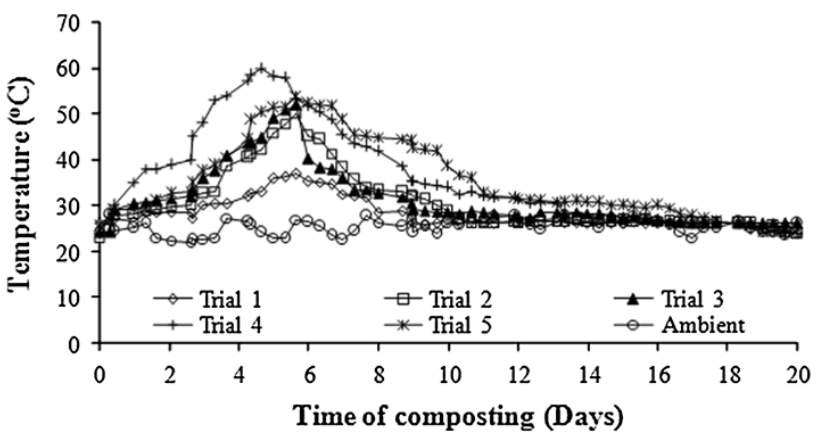

Fig. 1 Temperature profile during rotary drum composting

cattle manure and sawdust). The maximum temperature recorded by trials $2,3,4$, and 5 was $50.1,51.9,59.7$, and $53.6^{\circ} \mathrm{C}$ on sixth day, respectively. The highest peak of temperature $\left(59.7^{\circ} \mathrm{C}\right)$ was observed in trial 4 with waste composition of water hyacinth, cattle manure and sawdust (6:3:1) due to optimum proportion of raw materials. All the composting trials accomplished ambient temperature at the end of 20th day indicating the maturity of compost. It also indicated that the microbial activity has reduced due to decrease in the amount of degradable organic matter. Similar results have been obtained by Dhal et al. (2012) where maximum temperature was recorded as $57.3{ }^{\circ} \mathrm{C}$. Singh and Kalamdhad (2012) reported the maximum temperature of $56{ }^{\circ} \mathrm{C}$ during water hyacinth composting.

Moisture loss during the composting process can be viewed as an index of decomposition rate, because the heat generated is directly proportional to the evaporation rate of moisture in compost. However, optimum moisture content is necessary for the growth and survival of microorganisms. Higher moisture loss was observed in trial 5 $(27.42 \%)$ followed by trial 1 (23.53\%), 4 (19.69\%), 3 $(19.17 \%), 2(8.91 \%)$, respectively, at the end of composting period of 20th day (Fig. 2a). Leachate formation was not observed during composting period.

The $\mathrm{pH}$ of water hyacinth was observed between 6 and 8. Therefore, the composition of raw materials (cattle manure, sawdust, and water hyacinth) was taken such that the resultant $\mathrm{pH}$ lies in between 6 and 7.5, which is the most favorable condition for the growth of microorganisms. Nakasaki et al. (1993) tested the pH dependency of organisms active in the composting process and found the $\mathrm{pH}$ range of 7-8 to be optimum, whereas according to Bharadwaj (1995), the optimum $\mathrm{pH}$ for most microorganisms is between 6.5 and 7.5. Figure $2 \mathrm{~b}$ shows the variation of $\mathrm{pH}$ during composting of different trials. As per the results obtained, the initial $\mathrm{pH}$ for trials $1,2,3,4$, and 5 was $6.87,5.37,6.62,6.49$, and 6.63 , which further increased to $6.96,7.09,6.77,6.80$, and 7.37, respectively, at the end of composting period. Also, a slight decrease in $\mathrm{pH}$ was observed in all the trials between day 8 and day 12. But, for 

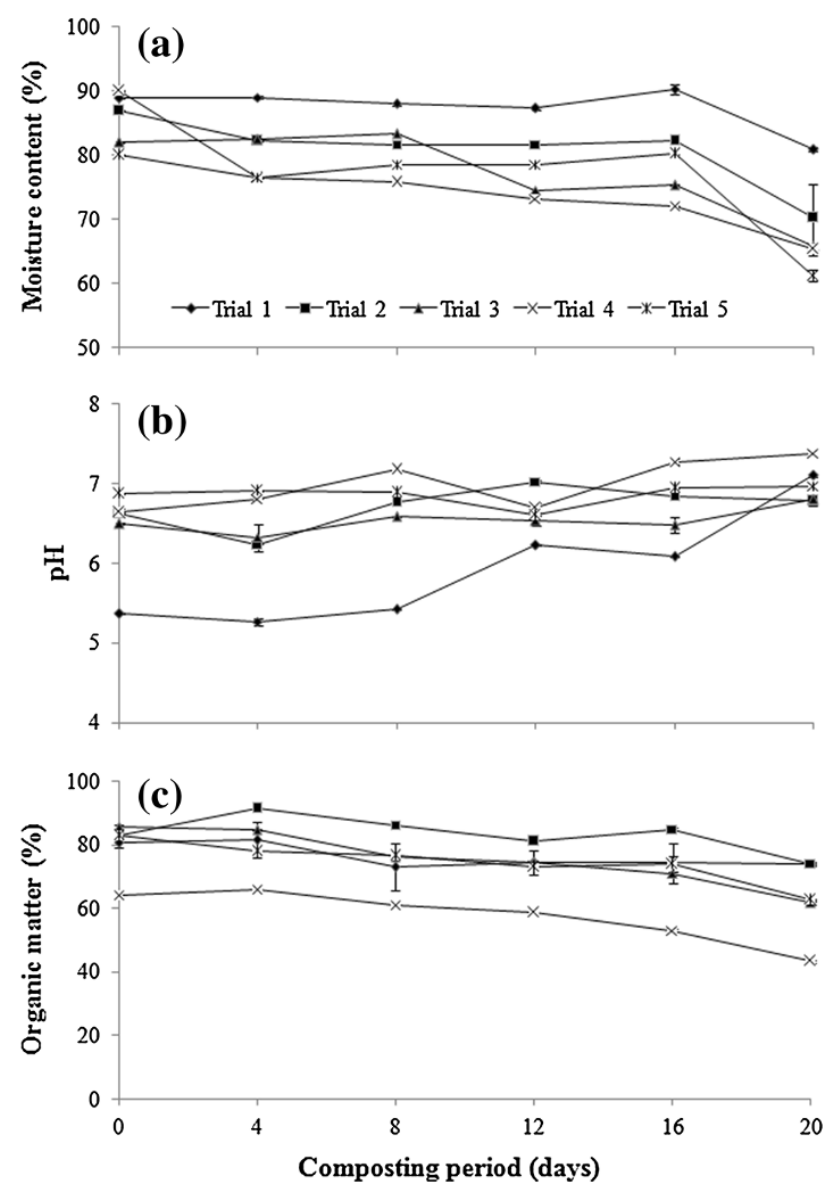

Fig. 2 Variation of moisture content, $\mathrm{pH}$ and organic matter during rotary drum composting

lignin degradation, it was observed that $\mathrm{pH} 4.5$ was optimum. The degradation suppresses below $\mathrm{pH} 3.5$ and above 5.5 (Kirk et al. 1978). The $\mathrm{pH}$ was not observed less than 6.2 in all the trials except the trial 1 (control). Hence, $\mathrm{pH}$ has not contributed for any lignin degradation. The slight decrease in $\mathrm{pH}$ during the initial period of composting was expected due to the formation of acid as a result of metabolism of readily available carbohydrates. Overall, the acceptable $\mathrm{pH}$ ranges were within levels tolerable to microorganisms. Neutral $\mathrm{pH}$ range was obtained at the end of composting in all the trials.

Figure 2c shows the degradation of organic matter during composting process. The maximum loss of organic matter was achieved in trial 4 (32.58\%). Most of the organic matter degraded during composting and consequently more oxygen consumed in trial 4 . The percentage loss of organic matter in trials $1,2,3$, and 5 was found as 7.96, 10.62, 27.95, and $24.52 \%$, respectively. At the end of composting period the amount of organic matter in the compost was determined to be $74,74,61.6,43.2$ and 62.5 in trials $1,2,3,4$ and 5, respectively. Organic matter is mostly degraded during thermophilic phase of composting where oxygen is consumed at higher rate by the microorganisms. Hence, it can be concluded that for organic matter degradation, temperature and moisture play a very significant role.

Figure 3a shows that total nitrogen (TN) was increased from 0.91 to $1.19 \%, 0.63$ to $0.98 \%, 0.58$ to $0.91 \%, 0.68$ to $1.05 \%$, and 0.91 to $1.54 \%$ in trials $1,2,3,4$, and 5 , respectively, within composting time. Highest TN was increased in trial $5(69.23 \%)$ followed by trial 3 $(56.99 \%)$, trial $2(55.56 \%)$ and trial $4(54.41 \%)$ and trial $1(30.77 \%)$ during the composting process. TN was increased in rotary drum composting due to the net loss of dry mass in terms of $\mathrm{CO}_{2}$ as well as the water loss by evaporation as a result of heat evolution during oxidization of organic matter (Kalamdhad et al. 2009a, b). The concentration of $\mathrm{NH}_{4}-\mathrm{N}$ was decreased from 97.8 to $77.1 \mathrm{mg} /$ $\mathrm{kg}$ in trial 1 , from 155.6 to $68.5 \mathrm{mg} / \mathrm{kg}$ in trial 2 , from 201.8 to $65.7 \mathrm{mg} / \mathrm{kg}$ in trial 3, from 148.5 to $22.7 \mathrm{mg} / \mathrm{kg}$ in trial 4 , and 69.7 to $43.4 \mathrm{mg} / \mathrm{kg}$ in trial 5 during the composting process (Fig. 3b). Higher reduction of $\mathrm{NH}_{4}-\mathrm{N}$ was observed in trial $4(84.7 \%)$ followed by trial $3(67.4 \%)$, trial $2(56.0 \%)$, trial $5(37.7 \%)$, and trial $1(21.1 \%)$ during the composting process (Fig. 3).The absence or decrease in $\mathrm{NH}_{4}-\mathrm{N}$ is an indicator of both high-quality composting process. High $\mathrm{pH}$, mixing and increased aeration have been exposed to enhance ammonia loss during maturation (Kalamdhad et al. 2009a, b). On analyzing the results by ANOVA, significant differences in nutrients were observed between the trials $(P<0.05)$. The total phosphorus was increased from 2.4 to $3.0,2.4$ to $4.0,2.8$ to 4.1, 2.3 to 4.6 , and 2.6 to $3.7 \mathrm{~g} / \mathrm{kg}$ in trials $1,2,3,4$ and 5 , respectively (Fig. 3c). The available phosphorus was also increased from 0.7 to $0.9,1.2$ to $2.4,1.5$ to $2.1,1.4$ to 2.0 , and 1.2 to $1.7 \mathrm{~g} / \mathrm{kg}$ in trials $1,2,3,4$, and 5 , respectively, during the composting process (Fig. 3d). Increase in total and available phosphorus concentration indicating the higher microbial activities during the composting process caused more mineralization; during mineralization process, net loss of compost mass was reduced (Kalamdhad et al. 2009a, b). The concentration of nutrients such as $\mathrm{Na}, \mathrm{K}$, $\mathrm{Ca}$, and $\mathrm{Mg}$ was increased in the range of 12-120, 9-72, 4-133, and 6-72\%, respectively, in all the trials during the process; it might be due to the net loss of dry mass (Singh and Kalamdhad 2013a).

Biochemical analysis

\section{Lignin (acid soluble and insoluble)}

Figure $4 \mathrm{a}$ shows the degradation of acid insoluble lignin in the compost environment. Lignin has a very complicated structure, which is highly resistant to microbial degradation (Hatakka 2001). Its degradation mainly occurs during 

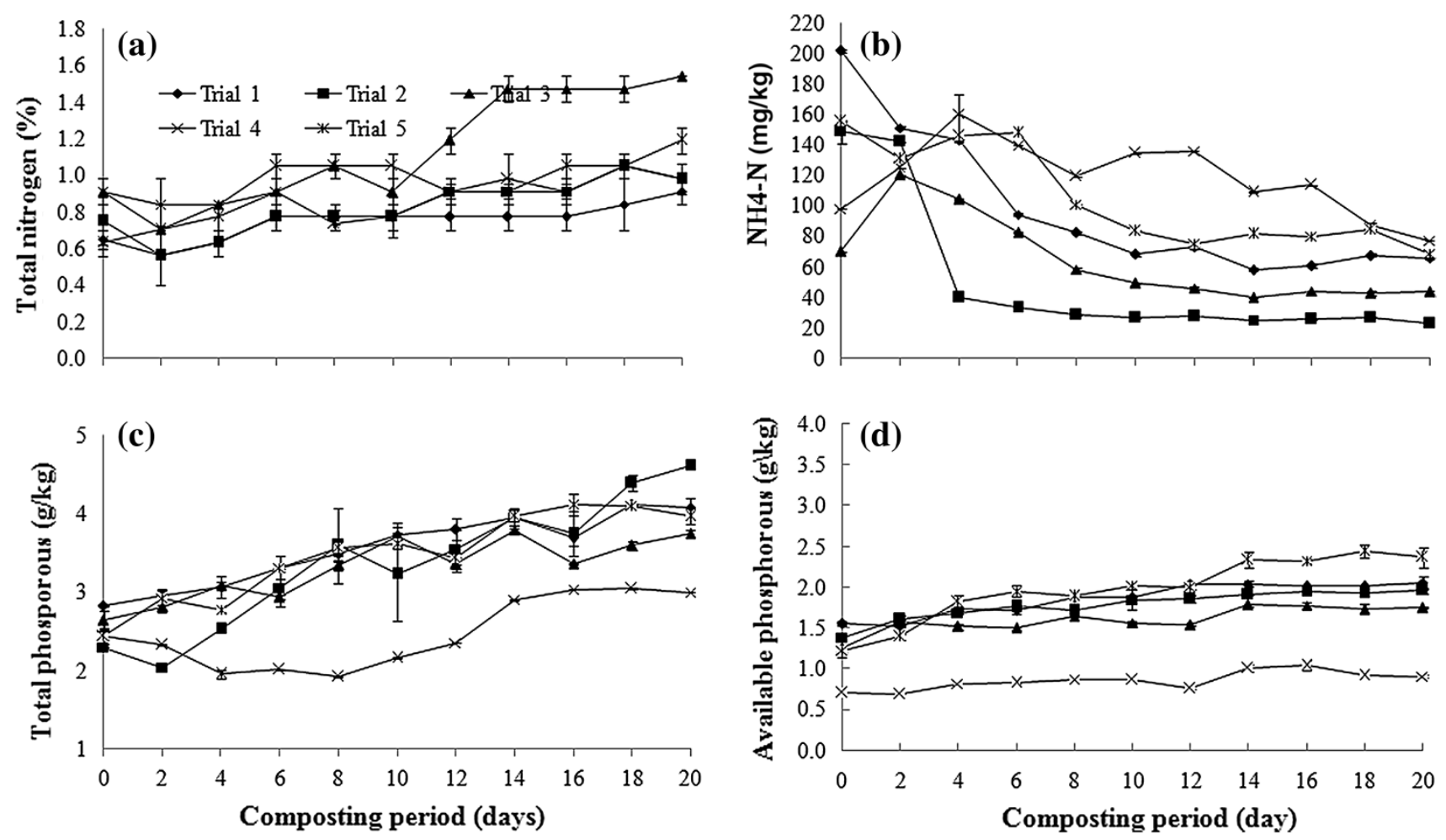

Fig. 3 Variation of total nitrogen, $\mathrm{NH}_{4}-\mathrm{N}$, total phosphorus, and available phosphorus during rotary drum composting

thermophilic phase of composting (Tuomela et al. 2000) and an optimum temperature of about $40-50{ }^{\circ} \mathrm{C}$ is required for the growth of thermophilic fungi and actinomycetes for a longer duration. Therefore, rotary drum composting method was adopted to achieve a high rate of degradation in amount of lignin present. Acid insoluble lignin was increased about $13.95 \%$ in trial 1 (control), whereas, it was reduced about $9.09,16.16,39.72$, and $10.29 \%$ in trials 2 , 3,4 and 5, respectively, during the composting process. During initial characterisation of raw materials, the percentage of acid insoluble lignin was found about 41.34 and $20.0 \%$ in sawdust and cattle manure, respectively. These raw materials contributed to the increase in amount of acid insoluble lignin present in the compost. The maximum biodegradation of acid insoluble lignin was observed in trial $4(39.72 \%)$ as compared to other trials. It can be attributed as; proper proportion of initial waste mixture enhanced the growth and activity of microorganisms. Since, lignin is difficult to degrade, the percentage of undegraded acid insoluble lignin was found to be 28.67, $35.67,46.67,28.33$, and $36.33 \%$ in trials $1,2,3$, 4, and 5, respectively, during the composting process. Regardless of adopting a high rate of composting method, the maximum reduction of $39.72 \%$ in acid insoluble lignin could be achieved during water hyacinth composting. Proper aeration by manual turning consequently achieving maximum thermophilic temperature was also contributing factors for the degradation of acid insoluble lignin. An optimum temperature of about $40-50{ }^{\circ} \mathrm{C}$ is required for thermophilic micro-fungi and actinomycetes to degrade lignin but, above $60{ }^{\circ} \mathrm{C}$, these microorganisms cannot grow and lignin degradation is slowed down (Tuomela et al. 2000). Therefore, complete degradation of lignin is not accomplished in any of the trials within 20 days. Feng et al. (2011) reported degradation of $11.74 \%$ of lignin during composting of lignocellulose material. Garcia et al. (2003) observed $60 \%$ decreases in lignin amount during composting of olive mill waste. Figure $4 \mathrm{~b}$ shows the degradation of acid soluble lignin. The higher reduction of acid soluble lignin was observed in trial $3(35.83 \%)$ followed by trial $4(25.89 \%)$, trial $2(16.13 \%)$, trial $5(7.92 \%)$, and trial $1(3.32 \%)$ during the composting process. The percentage of acid soluble lignin were observed about $2.71,1.30,0.77,0.83$, and $1.86 \%$ in trials $1,2,3,4$, and 5, respectively, in the final compost, which was very less as compared to insoluble lignin.

\section{Cellulose}

Cellulose is the major element of plant cell walls which provides them rigidity (Beguin and Albert 1994). Cellulose was found high in cattle manure $(49.87 \%)$, whereas in water hyacinth and sawdust, the percentage of cellulose was 15.78 and $37.89 \%$, respectively. Combination of these 

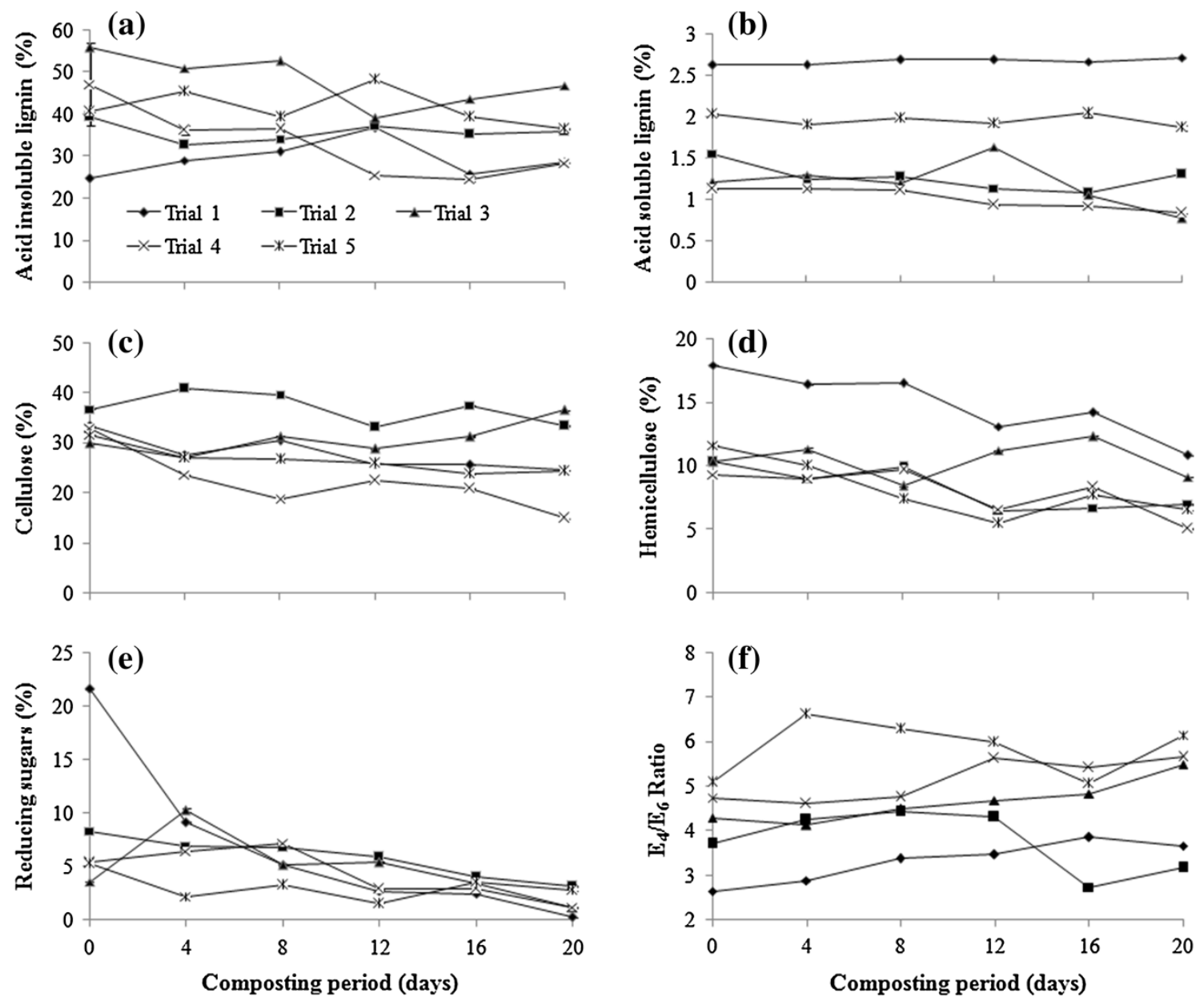

Fig. 4 Variation of acid insoluble, soluble lignin, cellulose, hemicelluloses, reducing sugar, and $\mathrm{E}_{4} / \mathrm{E}_{6}$ ratio during rotary drum composting

three raw materials might have resulted into higher amount of cellulose in all the trials. Since, the cellulose is easily degradable organic matter and its degradation starts the moment raw materials are piled up (Cooperband 2000). Therefore, the initial amount of cellulose present in trials 1 , $2,3,4$, and 5 was $33.25,36.69,41.89,32.92$, and $31.6 \%$, respectively. Figure $4 \mathrm{c}$ shows the degradation of cellulose during composting of water hyacinth. The highest degradation for cellulose was observed in trial 4 (55.07\%) due to proper combination of waste materials which resulted in better biological activity. The slow degradation of cellulose could be explained as the lignin attached strongly with cellulose (Kuhad et al. 1997). The degradation of cellulose in trials 1, 2, 3, 4 and 5 was obtained as 26.25, 9.02, 3.65, 55.07 and $23.16 \%$, respectively. At the end of composting period, the amount of un-degraded cellulose left in compost was found to be $24.52,33.38,40.36,14.79$ and $24.28 \%$, respectively, in trials 1, 2, 3, 4 and 5. Mesophilic bacteria, actinomycetes, fungi, and protozoa are the microorganisms which grow at temperature between 10 and $45^{\circ} \mathrm{C}$ i.e., during mesophilic phase to biodegrade raw materials
(Cooperband 2000) and break down easily degradable components such as sugars and amino acids (Hellmann et al. 1997). Parveen and Padmaja (2010) reported cellulose degradation of $31.55 \%$ in uninoculated and $20.56 \%$ in fungal consortium inoculated during composting of water hyacinth and municipal solid waste. Baddi et al. (2004) reported $58 \%$ reduction in cellulose in 12 months during olive mill composting.

\section{Hemicellulose}

Hemicellulose is a complex carbohydrate polymer and makes up 25-30\% of total wood dry weight. It primarily consists of five sugars D-xylose, D-mannose, D-galactose, Dglucose, and L-arabinose. It also has 4-O-methyl-glucuronic, D-galacturonic, and D-glucuronic acids. Sugars are linked together by $\beta-1,4-$ and occasionally $\beta-1,3$-glycosidic bonds (Perez et al. 2002). In contrast to cellulose, they are easily hydrolyzable polymers. They do not form aggregates, even when they are co-crystallized with cellulose chains. The maximum amount of $27 \%$ of 
hemicellulose was present in water hyacinth. The highest reduction of $45.16 \%$ in hemicellulose was obtained in trial 4. For trials 1, 2, 3, and 5, the reduction was observed as $39.66,32.03$, 11.65, and $43.96 \%$, respectively (Fig. 4d). Baddi et al. (2004) reported $76 \%$ reduction in hemicellulose in 12 months during olive mill composting. Zeng et al. (2010) reported maximum degradation of hemicellulose as compared to lignin and cellulose during composting. In all the five trials, it was found that the amount of hemicellulose present in the compost at the end of 20 days was less than $10 \%$ indicating very rapid degradation of hemicellulose under microbial activity.

\section{Reducing sugars}

Sugars with reducing property arising out of the presence of a potential aldehyde or keto group are called reducing sugars. Some of the reducing sugars are glucose, galactose, lactose, and maltose. In trial 1 , the amount of reducing sugars present initially was $21.61 \%$. Maximum reduction of $98.75 \%$ in reducing sugar was observed in trial 1 (control) in which no bulking agents were present. For trials $2,3,4$, and 5 , the degradation of reducing sugar is $62.38,67.3,77.1$, and $47.3 \%$, respectively (Fig. 4e). The reduction in reducing sugars may be attributed due to microbial assimilation as the composting proceeded. Parveen and Padmaja (2010) reported that reduction in reducing sugar was $0.67 \mathrm{mg} / \mathrm{g}$ in water hyacinth compost.

\section{$E_{4} / E_{6}$ ratio}

Formation of humic substance is important parameter of the mature compost; therefore, to study the changes in humification parameter $\mathrm{E}_{4} / \mathrm{E}_{6}$ ratio is widely adopted. It provides the quality of humic acid and aromatization level of compost. If the E4/E6 ratio is below five then the sample is characterized as humic acid, whereas if the ratio is above five then the sample is characterized as fulvic acid (Zorpas et al. 2008). In Fig. 4f, it was observed that E4/E6 ratio has increased in trials $1,3,4$ and 5. The magnitude of $\mathrm{E}_{4} / \mathrm{E}_{6}$ is associated with the degree of condensation of the aromatic carbon network; also it is independent of concentrations of humic materials (Zorpas et al. 2008). A low $\mathrm{E}_{4} / \mathrm{E}_{6}$ ratio indicates relatively high degree of condensation of aromatic humic constituents, whereas a high $\mathrm{E}_{4} / \mathrm{E}_{6}$ ratio shows a low degree of aromatic condensation and implies the presence of relatively large portions of aliphatic structures (Rivero et al. 2004). Low degree of aromatic carbon might have resulted due to short period of humification during composting process. The value of $\mathrm{E}_{4} / \mathrm{E}_{6}$ ratio for humic acids usually ranges between 2 and 5 and the results have been obtained within this range. Humic acids derived from compost usually have low degree of aromatic carbon and low-molecular weight (Velasco et al., 2004). Since, this $\mathrm{E}_{4} /$ $\mathrm{E}_{6}$ ratio should decrease with time; the same can be achieved if time allowed for compost maturity is increased. Rivero et al. (2004) observed a decrease in $\mathrm{E}_{4} / \mathrm{E}_{6}$ ratio on 3 -year-old compost. Huang et al. (2006) achieved a decrease in $\mathrm{E}_{4} / \mathrm{E}_{6}$ ratio from 3.53 to 2.50 in 63 days. Wei et al. (2007) also observed a decrease in value from 8.1 to 6.1 at the end of 63 days of MSW compost.

\section{FTIR spectroscopy}

Figure 5 shows IR spectra of trials 1, 2, 3, 4 and 5 during composting process. IR spectra were observed for all the five trials with variations in peak intensity of the band. A broad band at 3,400-3,300 $\mathrm{cm}^{-1}$ confirmed the hydrogen variations of alcoholic $(\mathrm{OH})$, phenolic or carboxylic groups $(\mathrm{COOH})$. Absorption peaks were observed at 2,930-2,920 $\mathrm{cm}^{-1}(\mathrm{C}-\mathrm{H}$ stretching vibrations of fatty acids, waxes and various aliphatic components). Peaks at $2,850 \mathrm{~cm}^{-1}$ show $\mathrm{C}-\mathrm{H}$ stretching vibrations in the presence of aliphatic methylene. Peaks at $1,630 \mathrm{~cm}^{-1}$ characterize aromatic $\mathrm{C}=\mathrm{C}$ vibrations and alkenes. Peaks at $1,510-1,520 \mathrm{~cm}^{-1}$ are assigned to aromatic skeletal of lignin and other lignocellulose components. Peaks at $1,430-1,420 \mathrm{~cm}^{-1}$ respond to signals generated by $-\mathrm{CH}-$, $-\mathrm{CH}_{2-}$ and $\mathrm{CH}_{3}$ radicals. Carbonates are also known for absorption at $1,420 \mathrm{~cm}^{-1}$. Peaks at $1,380 \mathrm{~cm}^{-1}$ confirm the presence of mineral constituents ( $\mathrm{N}-\mathrm{O}$ stretch). Ammonium bicarbonate is formed by reaction between ammonia and $\mathrm{CO}_{2}$ released during composting process. $1,320 \mathrm{~cm}^{-1}$ absorbs $\mathrm{C}-\mathrm{N}$ stretch with components such as primary aromatic and secondary amines. Peaks from 1,032 to $1,040 \mathrm{~cm}^{-1}$ absorb Si-O$\mathrm{Si}$ silicates, aromatic ethers and polysaccharides $(\mathrm{C}-\mathrm{H}$ stretch). The interpretation of spectra is based on work published by Baddi et al. (2004) and Singh et al. (2011).

Changes were observed only in the band intensity during the composting process, which suggests that compost composition was same throughout the composting period. A very slight reduction in aliphatic $\mathrm{C}$ peak at $2,930 \mathrm{~cm}^{-1}$ was observed, shoulder peak at around $2,850 \mathrm{~cm}^{-1}$ smoothened and disappeared by the end of the composting process in most of the trials. This can be explained by the microbes using aliphatic and peptide structures and carbohydrates such as polysaccharides, cellulose and hemicellulose to meet their energy needs. Quantitative evaluation of compost sample with different proportionates was done in terms of relative intensity ratios of selected absorbance band. Decrease in 2,930/1,030 (aliphatic Carbon/polysaccharide) was observed in trials 3 and 4 . The ratio of intensities decreased from 0.87 to 0.79 and 0.68 to 0.63 , respectively. The ratio of intensities 1,630/1,030 (aromatic carbon/polysaccharide) decreased from 0.90 to $0.85,0.90$ to $0.85,0.75$ to 0.74 , and 0.90 to 0.88 in trials 1 , 3,4 and 5, respectively. Similarly, decrease in intensity 

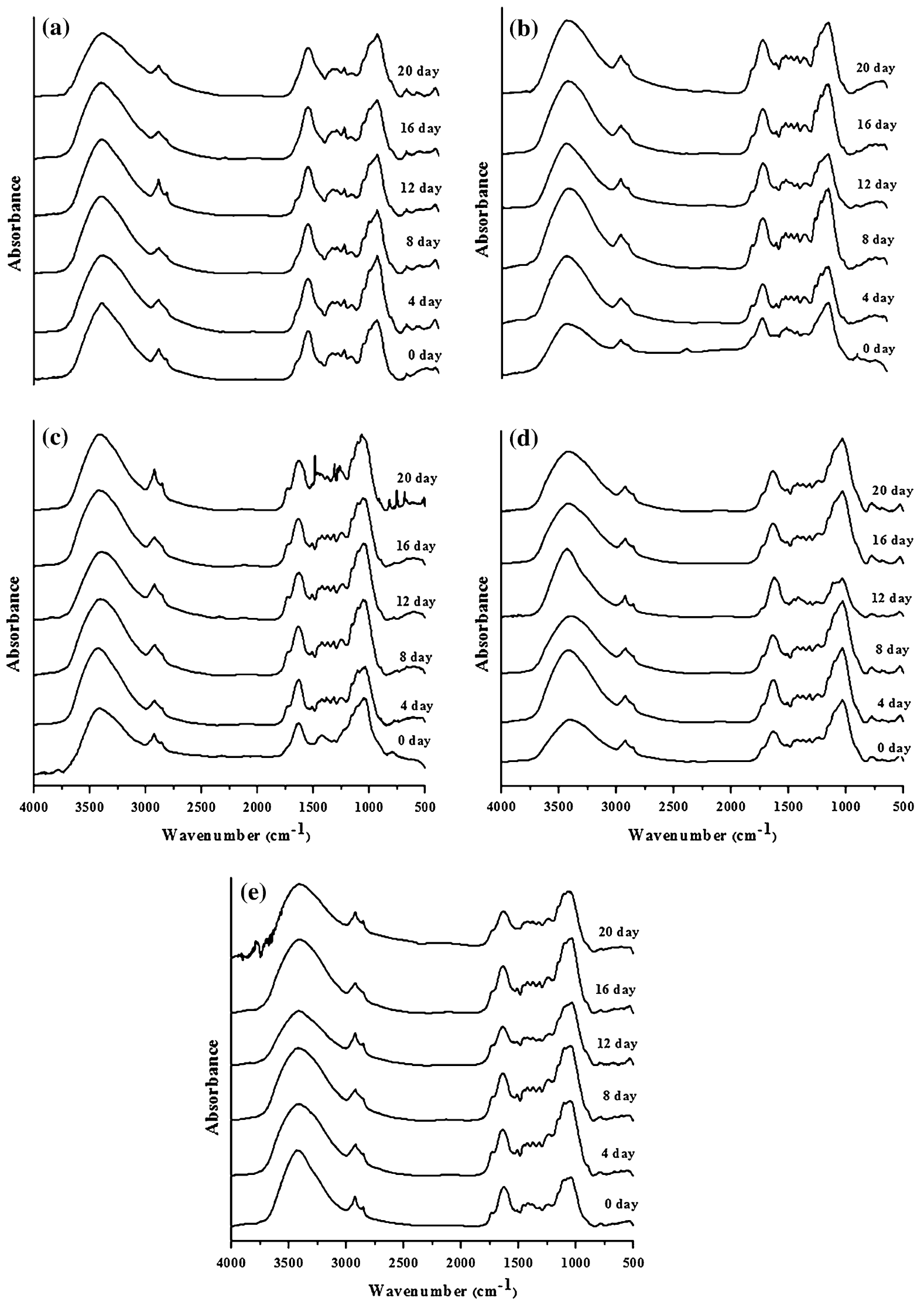

Fig. 5 IR spectroscopy of compost samples: a trial 1, b trial 2, c trial 3, d trial 4, and e trial 5 
ratio 2,930/1,630 (aliphatic carbon/aromatic carbon) was observed as 0.82 to $0.78,0.96$ to 0.93 , and 0.91 to 0.84 , in trials 1, 3 and 4, respectively. This shows that with increase in composting period, the compost was enriched in aromatic $\mathrm{C}=\mathrm{C}$ as compared with aliphatic carbon. Kalamdhad et al. $(2009 a, b)$ observed the similar trend in the ratio of intensities.

\section{Conclusion}

Rotary drum composter was extremely competent for making water hyacinth compost due to providing proper mixing, agitation and aeration for composting microorganisms. The maximum reduction in lignin, cellulose and hemicellulose was observed in trial 4 (6:3:1) in comparison to trials 1, 2, 3 and 5 during rotary drum composting of water hyacinth. In addition, maximum temperature and organic matter reduction was also observed in trial 4 . The nutrients contents (nitrogen, phosphorus, Na, K, Ca and $\mathrm{Mg}$ ) were increased significantly during the process. It was observed that hemicellulose was degraded at a faster rate as compared to cellulose and lignin, since it is easily hydrolysable substance under mesophilic stage of composting process. From the results of $\mathrm{E}_{4} / \mathrm{E}_{6}$ ratio, it was concluded that the time required for compost maturity can be increased; since, humification increases with maturity of compost. On analyzing the FTIR results, trial 4 showed that aliphatic and polysaccharides have easily degraded and aromatic compounds have increased with time in trial 4. Hence, it can be concluded that the trial 4 (6:3:1) could be beneficial to enhance the agronomic value of soil as compared to other trials. Furthermore, to achieve higher degradation of cellulose and lignin, combination of rotary drum with microbial inoculation can be proposed.

Acknowledgments The authors gratefully acknowledge the financial support of the Department of Science and Technology (DST), Government of India. We have modified the manuscript accordingly. The manuscript has been resubmitted to your journal. We look forward to your positive response.

Open Access This article is distributed under the terms of the Creative Commons Attribution License which permits any use, distribution, and reproduction in any medium, provided the original author(s) and the source are credited.

\section{References}

Abbasi SA, Ramasamy EV (1999) Anaerobic digestion of high solid waste in proceedings of eight national symposium on environment IGCAR, Kalpakkam, India, 220-224

APHA (2005) Standard methods for the examination of water and wastewater. 21st edition, American public health association, Washington
Baddi GA, Alburquerque JA, Gonzalvez J, Cegarra J, Hafidi M (2004) Chemical and spectroscopic analyses of organic matter transformations during composting of olive mill wastes. Int Biodeterior Biodegrad 54:39-44

Baruah JN (1984) An environmentally sound scheme for management of water hyacinth through its utilization. In: Proceeding of International Conference on Water Hyacinth, Hyderabad, India, pp 96-125

Beguin P, Albert JP (1994) The biological degradation of cellulose. FEMS Microbiol Rev 13:25-58

Bharadwaj KKR (1995) Improvements in microbial compost technology, a special reference to microbiology of composting. In: Khanna S, Mohan K (eds) Wealth from waste. Tata Energy Research Institute, New Delhi, pp 115-135

Center TD, Hill MP, Cordo H, Julien MH (2002) Water hyacinth in biological control of invasive plants in the eastern United States. Van Driesche RG, Lyon S, Blossey B, Hoddle MS and Reardon R (eds) Morgantown, WV USDA Forest Service, pp 41-64

Cooperband LR (2000) Composting: art and science of organic waste conversion to a valuable soil resource. Lab Med 31:283-289

Dhal GC, Singh RW, Khwairakpam M, Kalamdhad AS (2012) Composting of water hyacinth using sawdust/rice straw as a bulking agent. Int J Environ Sci 2(3):1223-1238

Ehrman T (1996) Determination of acid-soluble lignin in biomass. NREL CAT Task Lab Anal Procedure \#004

Feng C, Zeng G, Huang D, Hu S, Zhao M, Lai C, Huang C, Wei Z, Li $N$ (2011) Effect of ligninolytic enzymes on lignin degradation and carbon utilization during lignocellulosic waste composting. Process Biochem 46:1515-1520

Garcia GA, Roig A, Bernal MP (2003) Composting of the solid fraction of olive mill wastewater with olive leaves: organic matter degradation and biological activity. Bioresour Technol 86:59-64

Goering HD, Van SPJ (1975) Forage fibre analysis. US Dept of Agriculture Research Service, Washington

Gunnarsson CC, Petersen CM (2007) Water hyacinths as a resource in agriculture and energy production: a literature review. Waste Manage 27:117-129

Hatakka A (2001) Biodegradation of lignin. In Hofrichter M, Steinbüchel A (ed) Biopolymers. Lignin, humic substances and coal, Wiley, Weinheim, pp 129-180

Haug RT (1993) The practical handbook of composting engineering. Lewis Publishers, Boca Raton

Hellmann B, Zelles L, Palojarvi A, Bai Q (1997) Emission of climaterelevant trace gases and succession of microbial communities during open-windrow composting. Appl Environ Microbiol 63:1011-1018

Huang GF, Wu QT, Wong JWC, Nagar BB (2006) Transformation of organic matter during co-composting of pig manure with sawdust. Bioresour Technol 97:1834-1842

Kalamdhad AS, Ali Khwairakpam M, Kazmi AA (2009a) Organic matter transformation during rotary drum composting. Dyn Soil Dyn Plant 3:93-98

Kalamdhad AS, Singh YK, Khwairakpam M, Kazmi AA (2009b) Rotary drum composting of vegetable waste and tree leaves. Bioresour Technol 100:6442-6450

Kirk TK, Schultz E, Connor WJ, Lorenz LF, Zeiku JG (1978) Influence of culture parameters on lignin metabolism by Phanerochaetechrysosporium. Arch Microbiol 117:277-285

Kuhad RC, Singh A, Eriksson KEL (1997) Microorganisms and enzymes involved in the degradation of plant fiber cell walls. In Eriksson KEL (ed) Adv Biochem Eng Biotechnol 57:46-125

Malik A (2007) Environmental challenge vis a vis opportunity: the case of water hyacinth. Environ Int 33:122-138

Miller GL (1959) Dinitrosalicyclic acid reagent for determination of reducing sugar. J Anal Chem 31:426-428 
Nakasaki K, Yaguchi H, Sasaki M, Kubota H (1993) Effects of pH control on composting of garbage. Waste Manage Res 11:117-125

Parveen AA, Padmaja CK (2010) Bioconversion of municipal solid waste (MSW) and water hyacinth (WH) into organic manure by fungal consortium. J Sustainable Dev 3(1):91-97

Patel VB, Patel AR, Patel MC, Madamwar DB (1993) Effect of metals on anaerobic digestion of water hyacinth-cattle dung. Appl Biochem Biotechnol 43:45-50

Perez J, Munoz-Dorado J, de la Rubia T, Martinez J (2002) Biodegradation and biological treatments of cellulose, hemicellulose, and lignin: an overview. Int Microbiol 5:53-63

Rivero C, Chirenje T, Ma LQ, Martinex G (2004) Influence of compost on soil organic matter quality under tropical conditions. Geoderma 123:355-361

Singh J, Kalamdhad AS (2012) Concentration and speciation of heavy metals during water hyacinth composting. Bioresour Technol 124:169-179

Singh J, Kalamdhad AS (2013a) Assessment of bioavailability and leachability of heavy metals during rotary drum composting of green waste (Water hyacinth). Ecol Eng 52:59-69

Singh J, Kalamdhad AS (2013b) Effect of rotary drum on speciation of heavy metals during water hyacinth composting. Environ Eng Res 18(3):177-189

Singh J, Kalamdhad AS (2014) Influences of natural zeolite on speciation of heavy metals during rotary drum composting of green waste. Chem Speciat Bioavail 26(2):1-11

Singh J, Mishra NS, Uma Banerjee S, Sharma YC (2011) Comparative studies of physical characteristics of raw and modified sawdust for their use as adsorbents for removal of acid dye. Bioresources 6(3):2732-2743

Templeton D, Ehrman T (1995) Determination of acid-insoluble lignin in biomass. NREL CAT Task. Lab Anal Procedure \#003

Tiquia SM, Tam NFY (2000) Fate of nitrogen during composting of chicken litter. Environ Pollut 110:535-541

Tuomela M, Vikram M, Hatakka A, Itavaara M (2000) Biodegradation of lignin in a compost environment: a review. Bioresour Technol 72(2):169-183

Updegraff DM (1969) Semimicro determination of cellulose in biological materials. Anal Biochem 32:420-424

Van SPJ (1994) The nutritional ecology of the Ruminant, 2nd edn. Cornell University Press, Ithaca, p 476

Velasco MI, Campitelli PA, Ceppi SB, Havel J (2004) Analysis of humic acid from compost of urban wastes and soil by fluorescence spectroscopy. Agriscientia XXI(1):31-38

Wei Z, Xi B, Zhao Y, Wang S, Liu H, Jiang Y (2007) Effect of inoculating microbes in municipal solid waste composting on characteristics of humic acid. Chemosphere 68:368-374

Zeng G, Yu M, Chen Y, Huang D, Zhang J, Huang H, Jiang R, Yu Z (2010) Effects of inoculation with Phanerochaete chrysosporium at various time points on enzyme activities during agricultural waste composting. Bioresour Technol 101:222-227

Zorpas AA, Vassilis I, Loizidou M (2008) Heavy metals fractionation before during and after composting of sewage sludge with natural zeolite. Waste Manage 28:2054-2060 